\title{
Profiling of Impurities in Samples \\ of Synthetic Cannabinoids Seized from Illegal Circulation in the Siberian Region of the Russian Federation
}

\author{
Andrey V. Oberenko*a, \\ Sergey V. Kachin ${ }^{\text {b }}$ and Sergey A. Sagalakov ${ }^{\text {b }}$ \\ ${ }^{a}$ Criminal Expertise Centre of Directorate \\ for Law Enforcement in Transport Means \\ of Russian Ministry of Internal Affairs \\ for Siberian Federal District \\ 50 Lomonosov Str., Krasnoyarsk, 660058, Russia \\ ${ }^{b}$ Siberian Federal University \\ 79 Svobodny, Krasnoyarsk, 660041, Russia
}

Received 26.01.2018, received in revised form 17.03.2018, accepted 19.08.2018

This article discusses the analysis of a database, i. e. chromatogram and mass spectra that were received from subdivisions of Criminal Expertise Centre of Directorate for Law Enforcement in Transport Means of Russian Ministry of Internal Affairs for Siberian Federal District and former Main Directorate of Federal Narcotics Control Service of the Russian Federation for Krasnoyarsk Territory within 2012-2016 when studying synthetic cannabinoids samples confiscated from illegal trafficking. Typical profile impurities of synthesis reagents were identified, as well as of substances that are fillers for the most wide-spread classes of synthetic cannabinoids.

Keywords: synthetic cannabinoids, chromatogram, mass spectra, impurities profiling.

Citation: Oberenko A.V., Kachin S.V., Sagalakov S.A. Profiling of impurities in samples of synthetic cannabinoids seized from illegal circulation in the Siberian region of the Russian Federation, J. Sib. Fed. Univ. Chem., 2018, 11(3), 310-322. DOI: $10.17516 / 1998-2836-0077$.

\footnotetext{
(C) Siberian Federal University. All rights reserved

* Corresponding author E-mail address: krasandrew@mail.ru
} 


\title{
Профилирование примесей
}

\section{в образцах синтетических каннабиноидов, изъятых из незаконного оборота \\ в Сибирском регионе Российской Федерации}

\author{
А.В. Оберенко ${ }^{a}$, С.В. Качин ${ }^{\sigma}$, С.А. Сагалаков ${ }^{\sigma}$ \\ аЭкспертно-криминалистический иентр Управления \\ на транспорте МВД России \\ по Сибирскому федеральному округу \\ Россия, 660058, Красноярск, ул. Ломоносова, 50 \\ ${ }^{6}$ Сибирский федеральный университет \\ Россия, 660041, Красноярск, пр. Свободныий, 79
}

Проведен анализ массива данных - архива хроматограмм и масс-спектров, полученных в подразделениях Экспертно-криминалистического иентра Управления на транспорте МВД России по Сибирскому федеральному округу и бывшего Главного управления Федеральной службы Российской Федерации по контролю за оборотом наркотиков по Красноярскому краю в период с 2012 по 2016 гг., при исследовании изъятых из незаконного оборота образиов синтетических каннабиноидов. Идентифицированы типичные профильные примеси реагентов синтеза, а также веществ - наполнителей для наиболее распространенных классов синтетических каннабиноидов.

Ключевые слова: синтетические каннабиноиды, хроматограммы, масс-спектры, профилирование примесей.

At the present moment, on the illegal market of the psychoactive drugs, (PDs) synthetic cannabinoids (SCs) are widespread. They are a group of chemical compounds that are in particular used for making smoking blends [1-5]. High popularity of these blends especially among young people is conditioned by their availability, low cost and expected safety in comparison with classic narcotics. Rocketing up of the number of involved in SCs consumption and related issues of antisocial behaviour, as well as development of all possible diseases make systematic approach to studying and solving this issue very topical.

Modern analytical chemistry in forensics first identifies the object and its source of origin. By the Government resolution of the Russian Federation No. 1186 as of 31 December 2009, certain range of SCs was included in List I of narcotic drugs that are illegal in the Russian Federation market. From that time, expert services of the Internal Affairs Ministry and Federal Drug Control Service of the Siberian Federal District received several thousand PDs samples for testing from illegal PDs market. As a rule, made research payed the most attention to identification of main SCs components and lesser attention to accompanying impurities. Together with that, information about ingredients and impurity content is considered as very important in order to identify 
community of SCs origin [6, 7]. This article is aimed to profile impurities in earlier studied SCs containing samples.

\section{Results and their discussion}

As a base material, over 1,000 chromatograms were used, which were received from subdivisions of Criminal Expertise Centre of Directorate for Law Enforcement in Transport Means of Russian Ministry of Internal Affairs for Siberian Federal District and former Main Directorate of Federal Narcotics Control Service of the Russian Federation for Krasnoyarsk Territory within 2012-2016 when studying SCs containing samples confiscated from illegal trafficking. Analytical measurement procedures are described in [8,9]. A short description of the Instruments and analysis conditions are given below. Samples were extracted with methanol. Then they were analysed using GC-MS. Equipment on which gas chromatography-mass spectrograms were made: chromatograph "Kristall 5000.2" (Russia) with a quadrupole mass-spectrometer detector "ISQ", chromatograph "Agilent 6890" with a quadrupole mass-spectrometer detector 5973. Analysis conditions: electron impact ionization (power of $70 \mathrm{eV}$ ); fused silica columns $30 \mathrm{~m}$ in length and $0.32 \mathrm{~mm}$ in diameter, with a methylpolysiloxane phase containing $5 \%$ of phenyl groups (type HP-5MS); evaporator temperature $-280{ }^{\circ} \mathrm{C}$; detector interface temperature $-280{ }^{\circ} \mathrm{C}$; initial column temperature $-100{ }^{\circ} \mathrm{C}$; final column temperature $-300{ }^{\circ} \mathrm{C}$; rate of column temperature elevation $-15^{\circ} \mathrm{C} / \mathrm{min}$; holding time at the final temperature $-10 \mathrm{~min}$; carrier gas - helium; carrier gas flow rate - $1.0 \mathrm{ml} / \mathrm{min}$; sample injection mode - split (Split 40:1).

Components were identified using the software AMDIS v 2.72 both in automatic and manual regimes using the following open-source libraries: SWGDRUG, Cayman Spectral Library and departmental libraries of psychoactive substances (EKBDRUGS).

Nominally profiled blends in which SCs may be represented firstly by initial components (synthesis reagents, dissolving agents) related to the methods, terms and production places of SCs and secondly filling substances (diluent) which may be added at any part of consumption distribution chain.

\section{Impurities profiling related to SCs synthesis}

Information about SC: main active substances, names, structures, initial synthesis reagents and typical impurities, which were identified in confiscated SCs samples, are presented in Table.

\section{Impurities in SCs synthesis initial reagents}

Among identified impurities in SCs synthesis reagents, three groups may be determined: main synthesis reagents of certain SCs classes, additional reagents, used at the final stage of individual SCs synthesis and supplementary reagents ( $\mathrm{pH}$ regulators and other media characteristics).

In SCs of indole-3-carboxamide class, as impurities of main synthesis reagents N-Pentylindole and N-(5-Fluoropentyl)indole are identified, as additional ones-1-Isocyanatoadamantane and Amantadine. Moreover, 1,3-Dicyclohexylurea was identified, which probably is the hydrolysis product of N,N'-Dicyclohexylcarbodiimide, which is an supplementary reagent in synthesis of amides and anhydrides [10]. In Fig. 1, as an example of the sample chromatogram of SCs named N-(Adamantan1-yl)-1-(5-fluoropentyl)-1H-indole-3-carboxamide (ACBM-2201) is given with identified impurities of additional synthesis reagents of 1-Isocyanatoadamantane and Amantadine. Besides presence of the latter illustrates the SCs synthesis scheme is presented in [11]. 


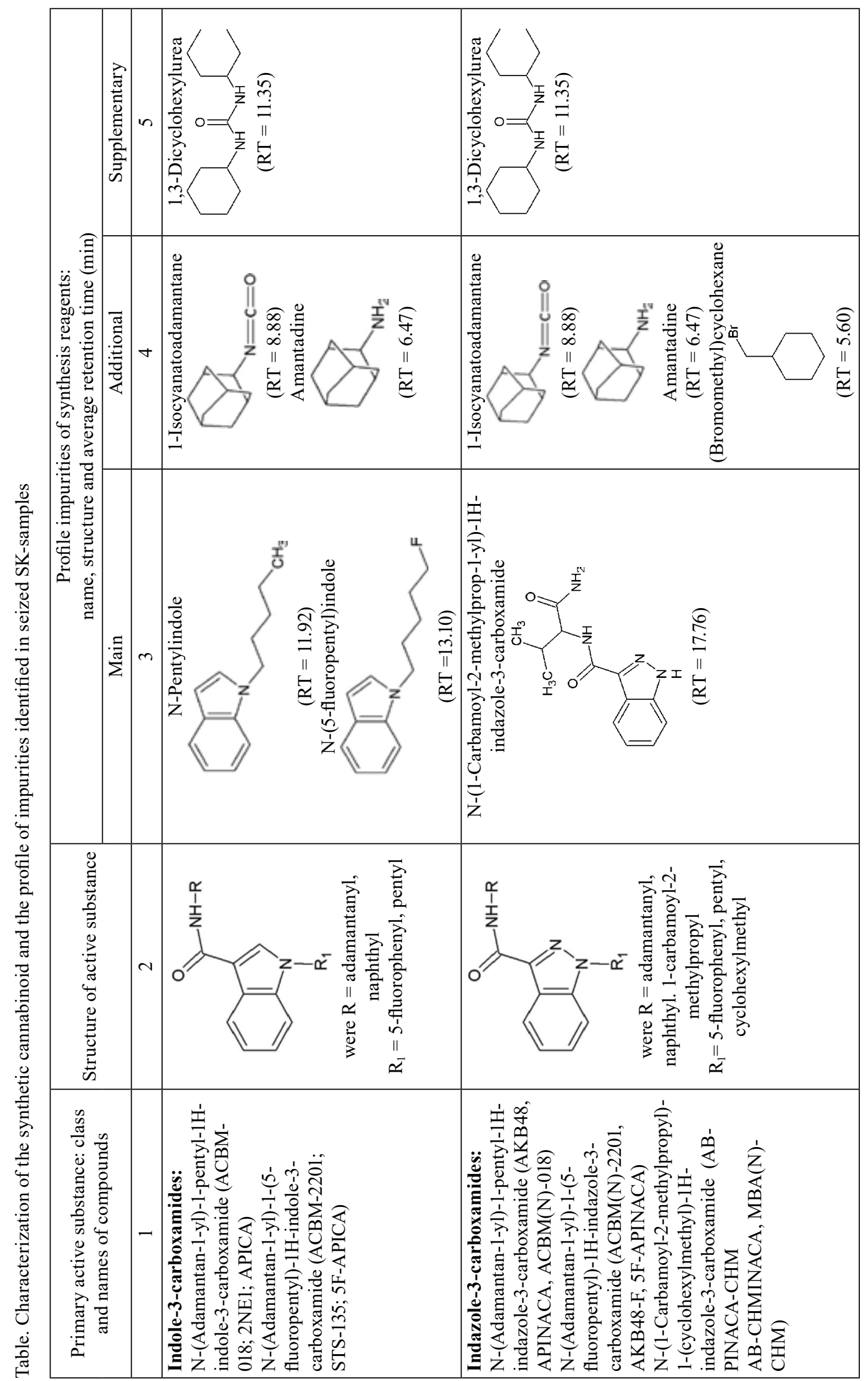




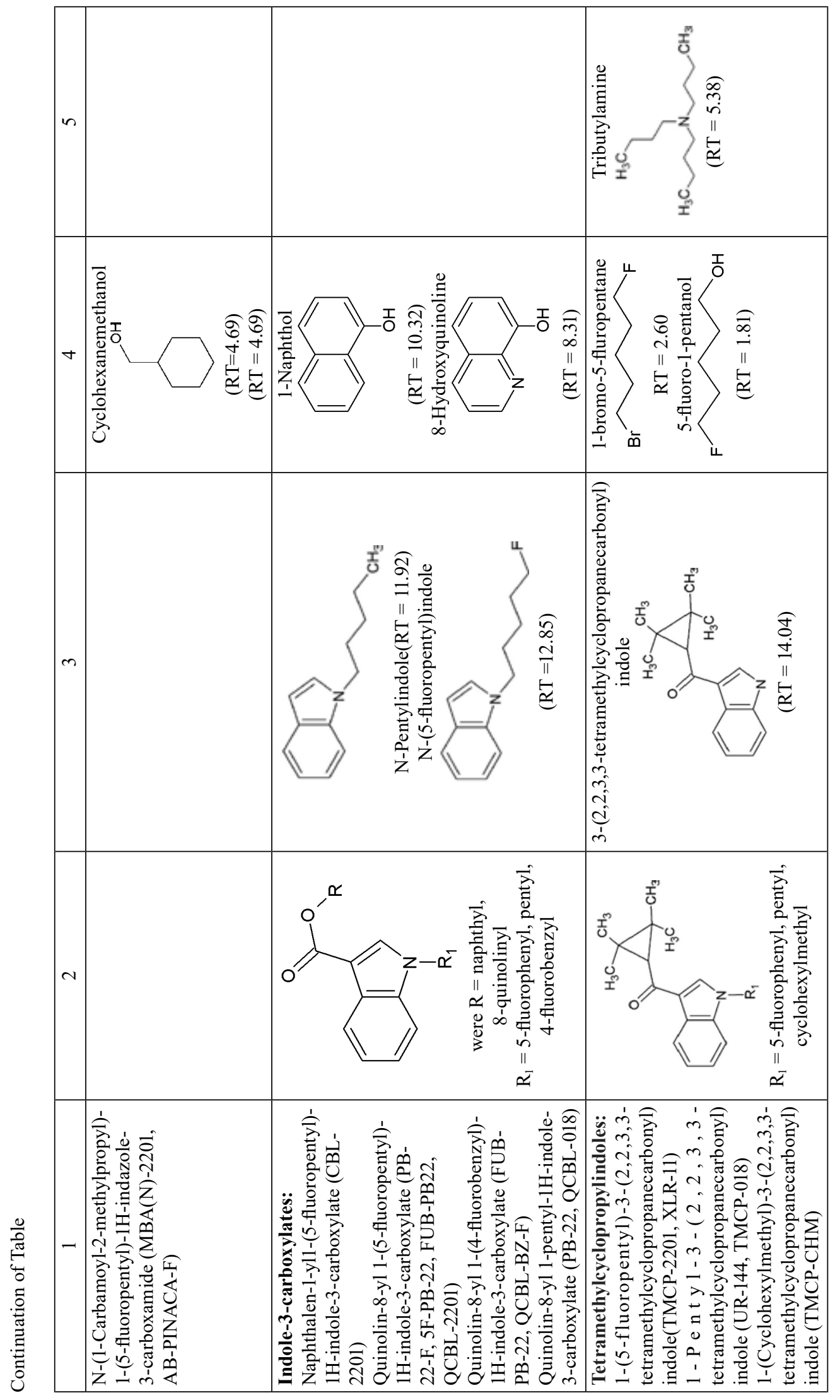




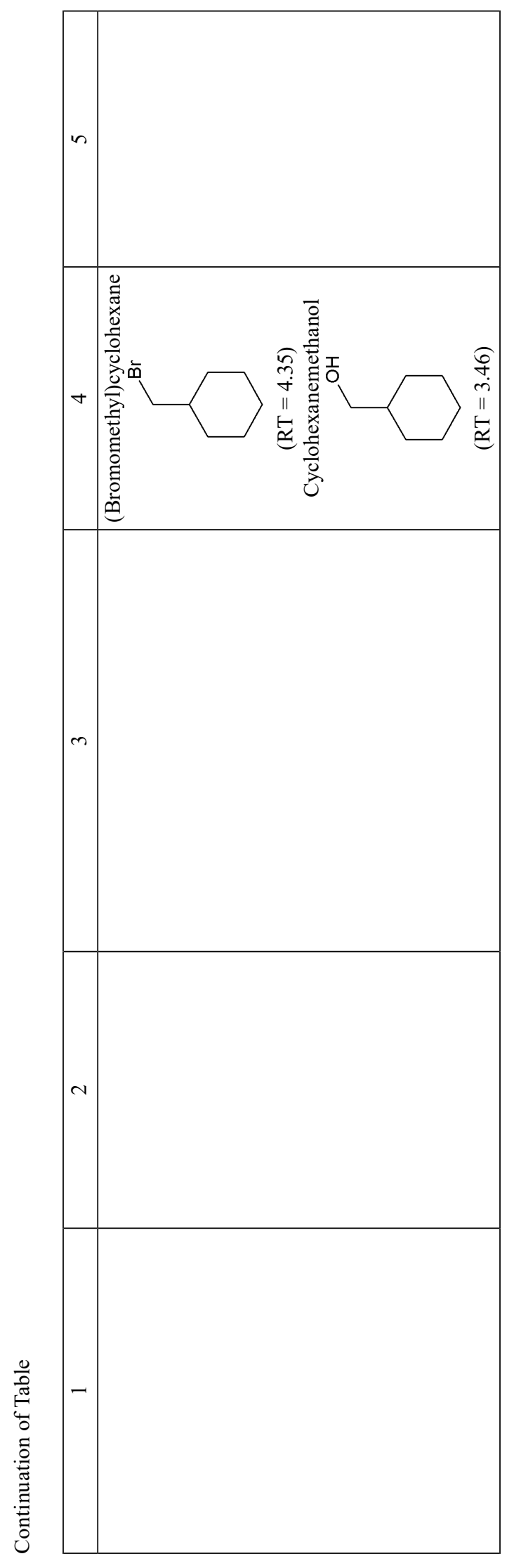


Other chromatogram spikes supposedly refer to vegetable filling substances.

Typical mass spectra of SCs synthesis reagent impurities of indole-3-carboxamide class are shown in Fig. 2-6.

In SCs samples of indazole-3-carboxamide class, confiscated in 2012-2013, synthesis reagent impurities, such as N-(1-Carbamoyl-2-methylprop-1-yl)-1H-indazole-3-carboxamide, 1-Isocyanatoadamantane, Amantadine and 1,3-Dicyclohexylurea, were also identified. However, since 2014 in SCs samples, (Bromomethyl) cyclohexane and Cyclohexanemethanol have been identified as

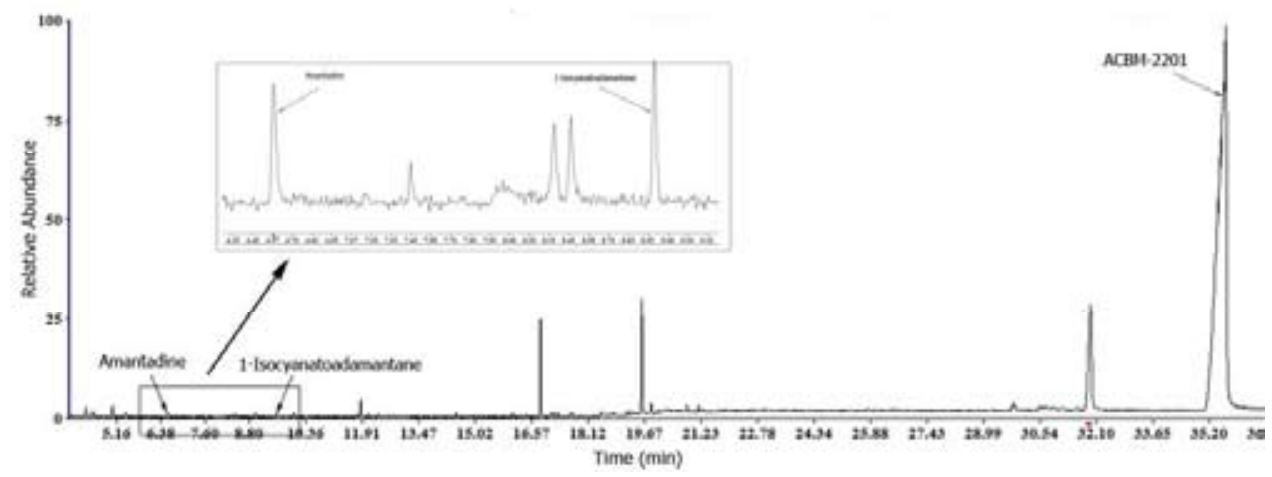

Fig. 1. The sample chromatogram of SCs named N-(Adamantan-1-yl)-1-(5-fluoropentyl)-1H-indole-3-carboxamide (ACBM-2201)

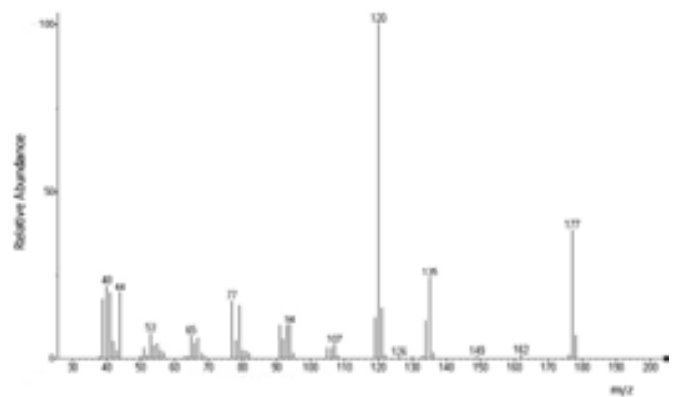

Fig. 2. Mass spectrum of N-Pentylindole

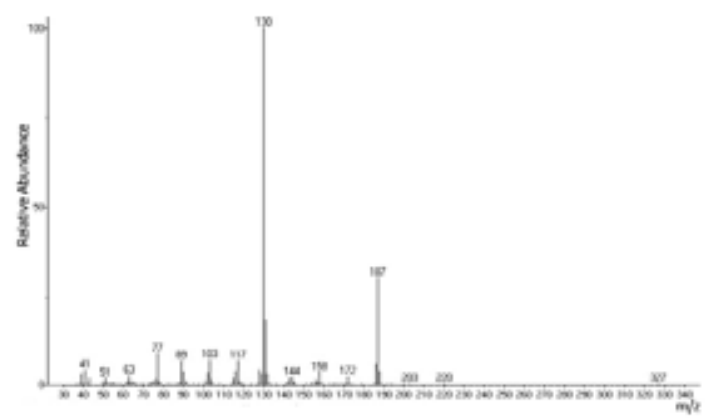

Fig. 4. Mass spectrum of 1-Isocyanatoadamantane

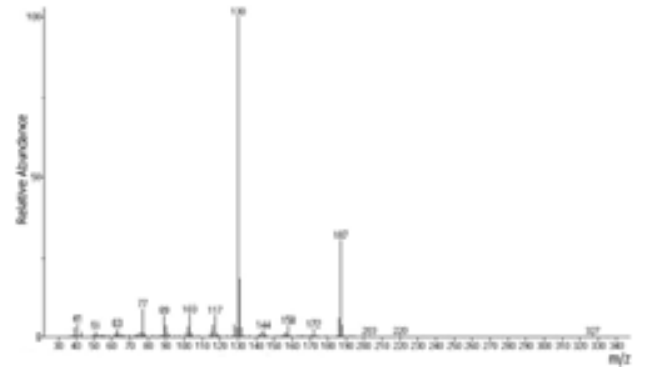

Fig. 3. Mass spectrum of N-(5-luoropentyl)indole

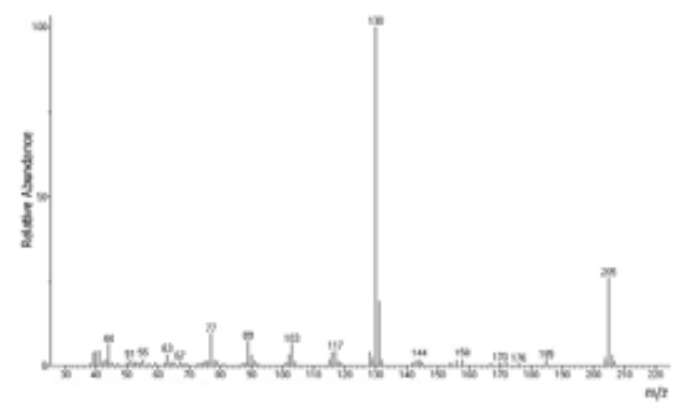

Fig. 5. Mass spectrum of Amantadine 
additional synthesis reagents. In Fig. 7, the sample chromatogram of SCs named N-(1-Carbamoyl2-methylpropyl)-1-(cyclohexylmethyl)-1H-indazole-3-carboxamide (AB-PINACA-CHM) is shown. Fig. 8-10 illustrates mass spectra of impurities synthesis.

For SCs class of indole-3-carboxylate identified impurities of main synthesis reagents are N-Pentylindole and N-(5-Fluoropentyl) indole, while 1-Naphthol and 8-Hydroxyquinoline are additional ones.

Besides, 8-Hydroxyquinoline is identified in nearly all the samples, while 1-Naphthol just in $25 \%$ of samples.

Fig. 11 illustrates the sample chromatogram of SCs named Quinolin-8-yl 1-(5-fluoropentyl)1H-indole-3-carboxylate (QCBL-2201). Fig. 12 illustrates the sample chromatogram of SCs named Naphthalen-1-yl 1-(5-fluoropentyl)-1H-indole-3-carboxylate (CBL-2201). Fig. 13-14 illustrate the typical mass spectra of 8-Hydroxyquinoline and 1-Naphthol.

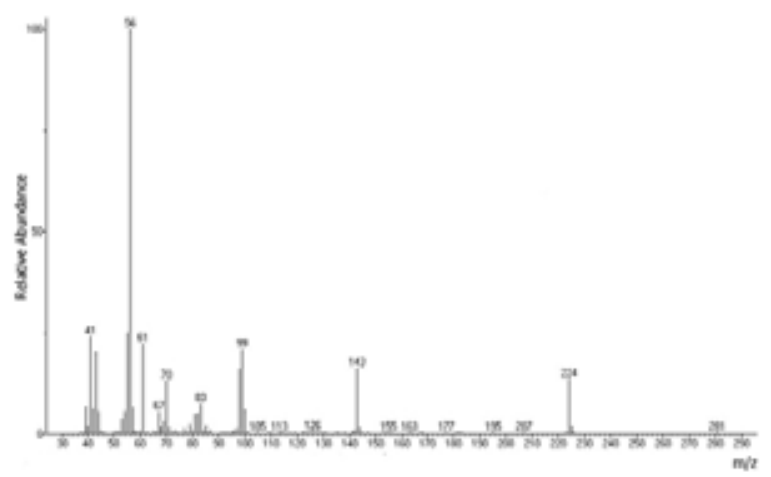

Fig. 6. Mass spectrum of 1,3-Dicyclohexylurea

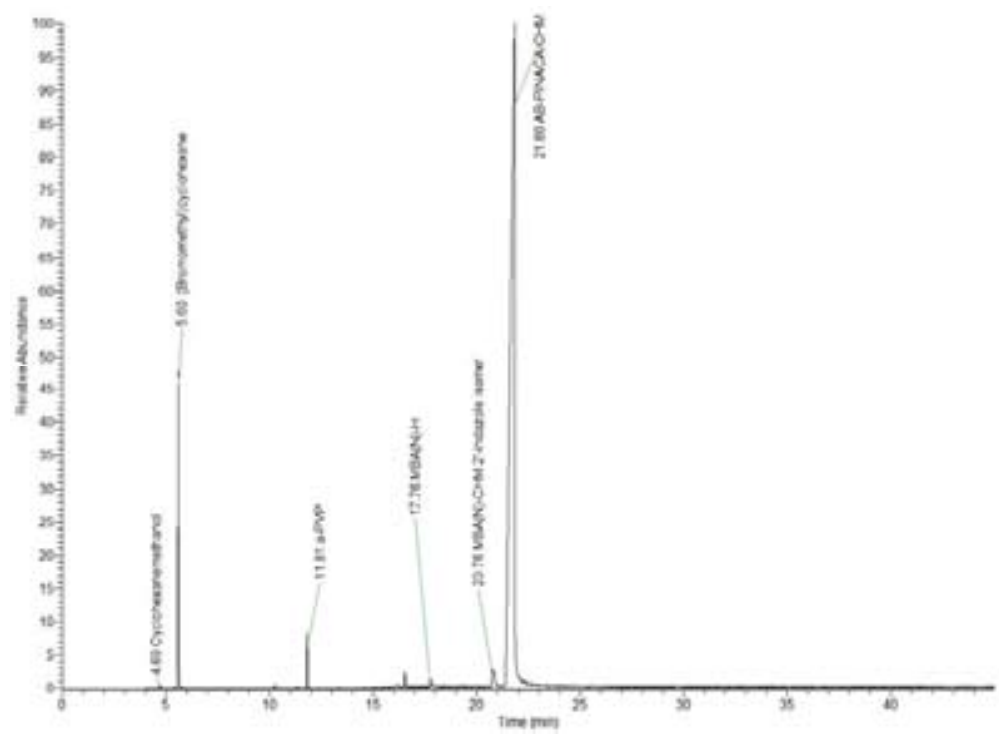

Fig. 7. The sample chromatogram of SCs named N-(1-Carbamoyl-2-methylpropyl)-1-(cyclohexylmethyl)-1Hindazole-3-carboxamide (AB-PINACA-CHM) 


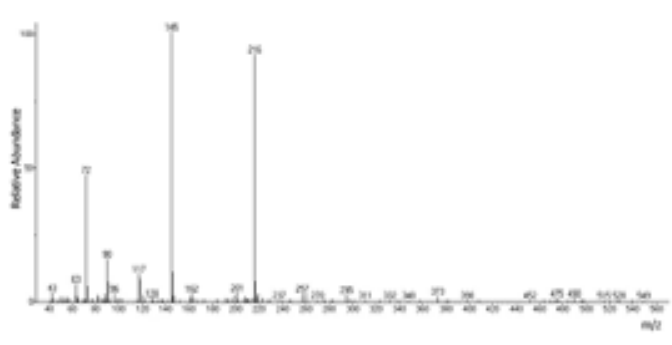

Fig. 8. Mass spectrum of N-(1-Carbamoyl-2methylprop-1-yl)-1H-indazole-3-carboxamide

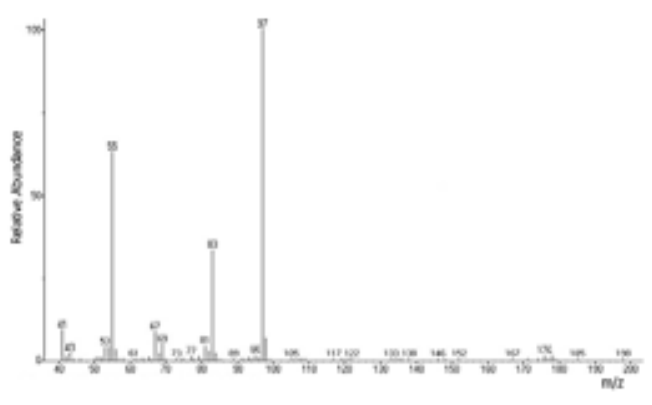

Fig. 9. Mass spectrum of Bromomethyl)cyclohexane

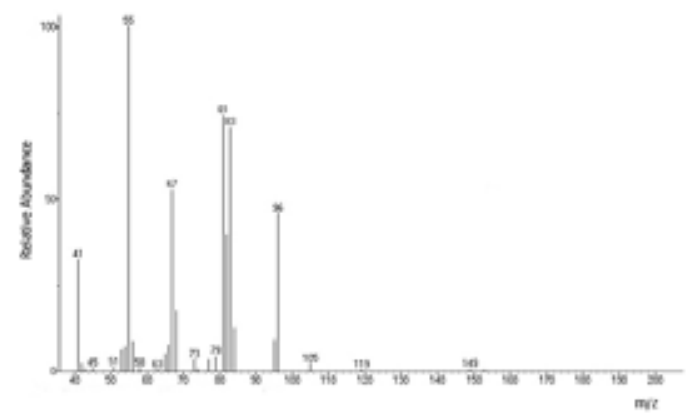

Fig. 10. Mass spectrum of Cyclohexanemethanol

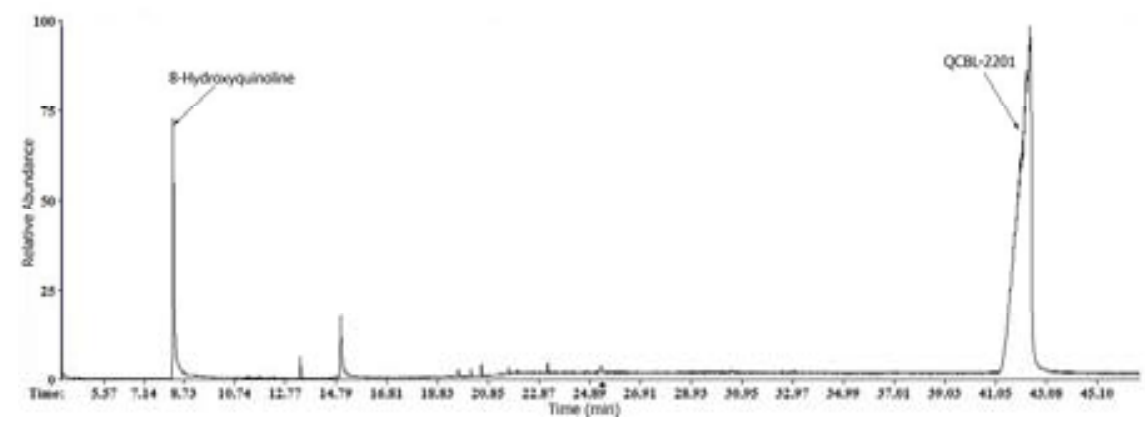

Fig. 11. The sample chromatogram of SCs named Quinolin-8-yl 1-(5-fluoropentyl)-1H-indole-3-carboxylate (QCBL-2201)

For SCs of tetramethylcyclopropylindoles, 3-(2,2,3,3-Tetramethylcyclopropanecarbonyl) indole is an identified impurity of the main synthesis reagent. 1-Bromo-5-fluropentane and (Bromomethyl) cyclohexane are identified as impurities of additional reagents, as well as 5-Fluoro-1-pentanol and Cyclohexanemethanol as corresponding hydrolysis products. Tributylamine is identified as a supplementary synthesis reagent (Fig. 15).

In Fig. 16-19, mass spectra examples of synthesis reagent impurities from tetramethylcyclopropylindoles class. 


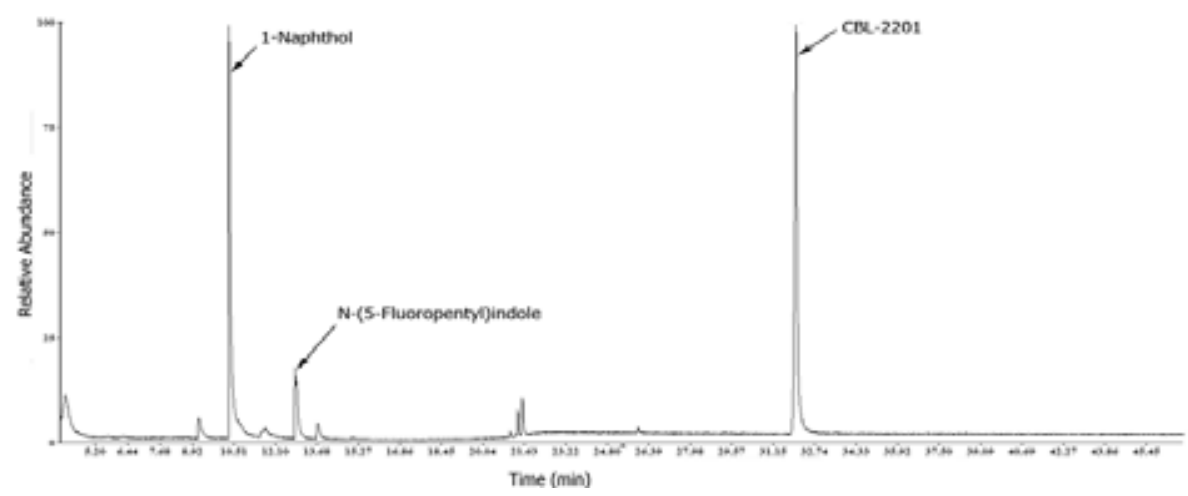

Fig. 12. The sample chromatogram of SCs named Naphthalen-1-yl 1-(5-fluoropentyl)-1H-indole-3-carboxylate (CBL-2201)

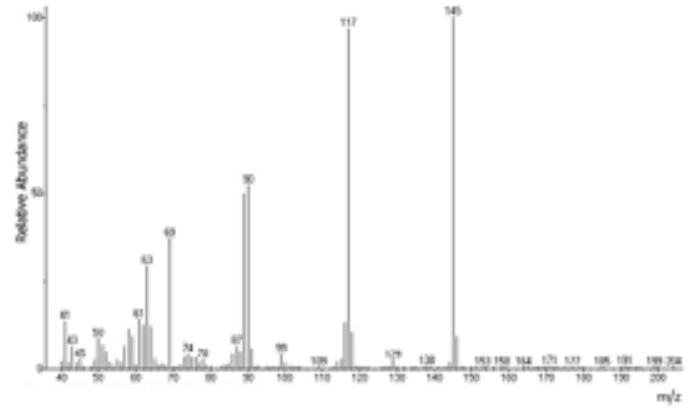

Fig. 13. Mass spectrum of 8-Hydroxyquinoline

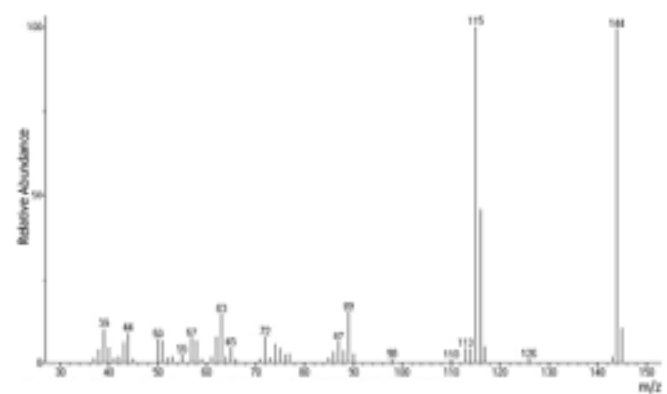

Fig. 14. Mass spectrum of 1-Naphthol

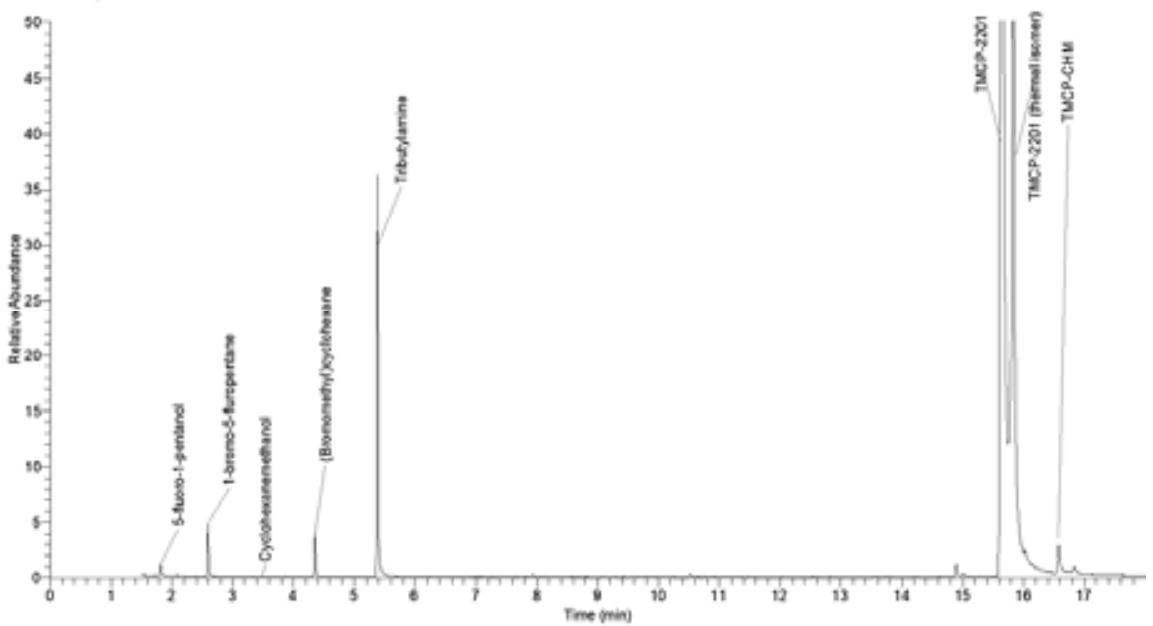

Fig. 15. The sample chromatogram of SCs named 1-(5-Fluoropentyl)-3-(2,2,3,3-tetramethylcyclopropanecarbonyl) indole (TMCP-2201) and 1-(Cyclohexylmethyl)-3-(2,2,3,3-tetramethylcyclopropanecarbonyl) indole (TMCPCHM) 


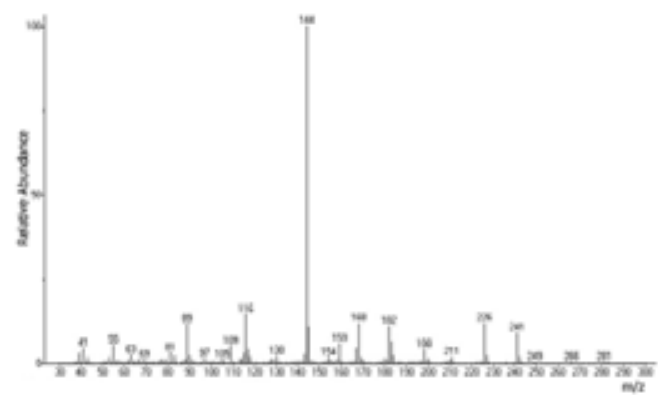

Fig. 16. Mass spectrum of 3-(2,2,3,3-Tetramethylcyclopropanecarbonyl)indole

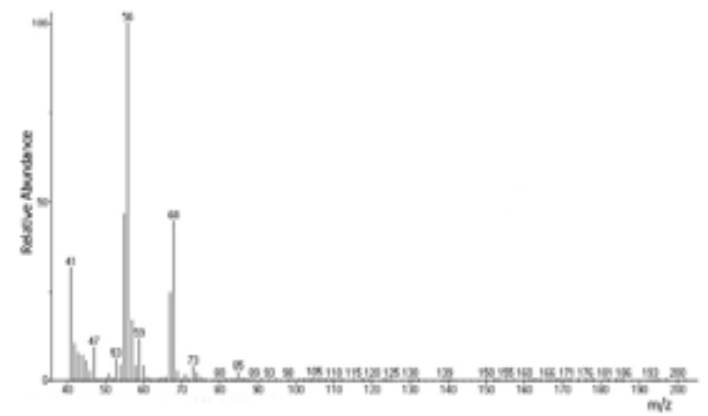

Fig. 18. Mass spectrum of 5-Fluoro-1-pentanol

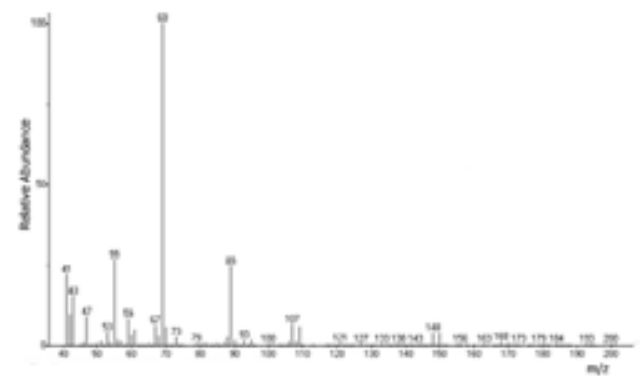

Fig. 17. Mass spectrum of 1-Bromo-5-fluropentane

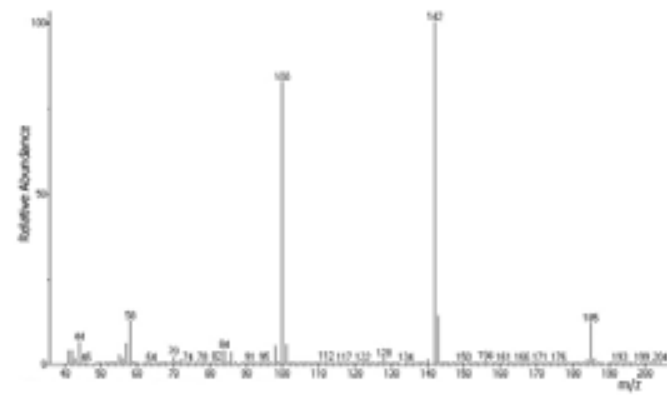

Fig. 19. Mass spectrum of Tributylamine

It should be mentioned that identified impurities composition correlates with the synthesis schemes given in reviews of WHO [11-14].

Despite the fact that SCs of different classes have different chemical nature, the basis for their synthesis is relatively a small number of initial compounds. For example, N-Pentylindole and N-(5Fluoropentyl) indole are main synthesis reagents for the synthesis of SCs named indole-3-carboxamide and indole-3-carboxylate. In the same time, content of main synthesis reagents, as a rule, is significantly lower than additional ones. The presence of latter in SCs samples in various combinations and concentrations can be considered as an additional factual material with clear forensic importance, which characterizes both SCs production method and storage conditions.

\section{Impurities profiles related to a filler (dissolving agent)}

Up to $90 \%$ of mass of SCs containing blends is an inter filler (dissolving agent). In Krasnoyarsk Territory since 2015, transition from dry vegetable fillers to solid fillers with specific generally sweet (vanilla, chocolate) smell is noticed. Mentioned smoking blends are in colloquial terms called chocolate. Typical components for these type fillers are glycerine, triacetin, fatty acids, products of sugar thermal decomposition, caffeine, theobromine, etc. Fig. 20 illustrates the sample chromatogram of flexible smoking blend containing N-(1-Carbamoyl-2,2-dimethylpropyl)-1-(4-fluorophenylmethyl)-1Hindazole-3-carboxamide (ADB-FUBINACA) with caffeine (RT (retention time) $=12.41$ ), theobromine $(\mathrm{RT}=12.52)$ and nicotine $(\mathrm{RT}=8.43)$. 


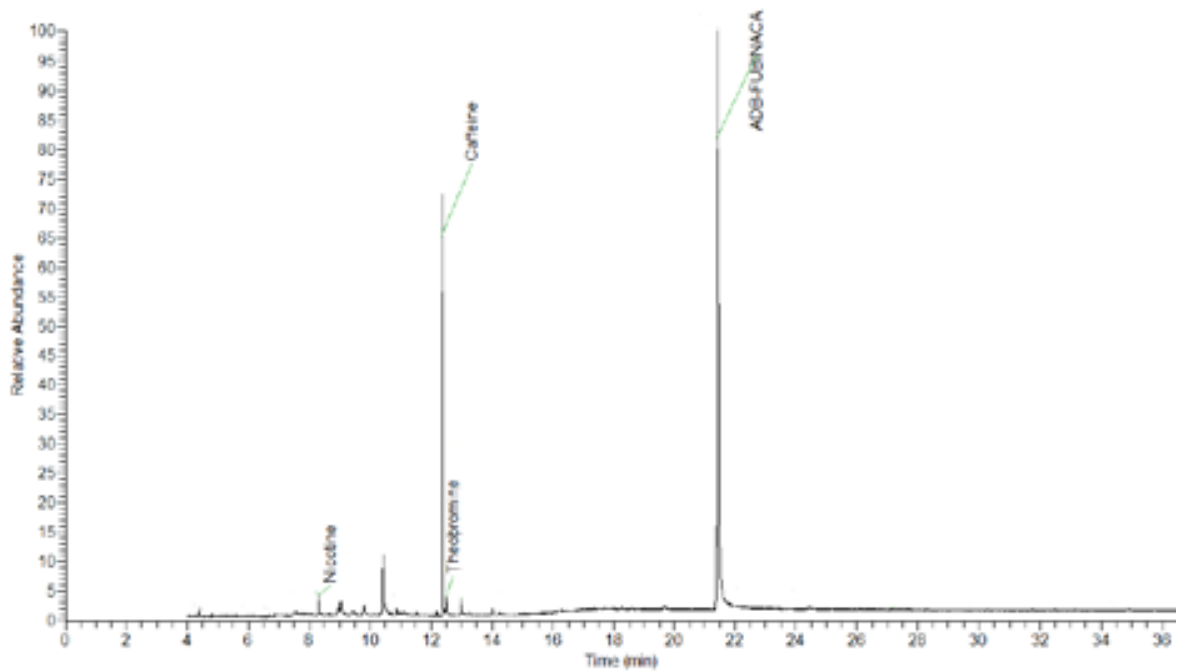

Fig. 20. Chromatogram of ADB-FUBINACA smoking blend

Thus, as the research result, typical profile impurities of synthesis reagents and filling substances are determined which are typical for the most wide-spread SCs confiscated from illegal trafficking in Siberian region of the Russian Federation. Obtained information on composition and impurities content is considered very important as an additional factual material in order to find evidence of place, method and terms of SCs obtainment, as well as delivery conditions.

\section{Reference list}

1. Auwärter V., Dresen S., Weinmann W., Müller M., Pütz M., Ferreirós N. "Spice" and Other Herbal Blends: Harmless Incense or Cannabinoid Designer Drugs? Journal of Mass Spectrometry 2009. Vol. 44(5), P. 832-837.

2. Simolka K., Lindigkeit R., Schiebel H.M., Papke U., Ernst L., Beuerle T. Analysis of Synthetic Cannabinoids in "spice-like" Herbal Highs: Snapshot of the German Market in Summer 2011. Analytical and Bioanalytical Chemistry 2012. Vol. 404(1), P. 157-171.

3. Piggee C. Investigating a Not-so-Natural High. Analytical Chemistry 2009. Vol. 81(9), P. 3205-3207.

4. Uchiyama N., Kikura-Hanajiri R., Goda Y. Identification of a Novel Cannabimimetic Phenylacetylindole, Cannabipiperidiethanone, as a Designer Drug in a Herbal Product and Its Affinity for Cannabinoid CB1 and CB2 Receptors. Chemical and Pharmaceutical Bulletin 2011. Vol. 59(9), P. $1203-1205$.

5. Zimmermann U.S., Winkelmann, P.R., Pilhatsch M., Nees J.A., Spanagel R., Schulz K. Withdrawal Phenomena and Dependence Syndrome After the Consumption of "Spice Gold". Deutsches Ärzteblatt International 2009. Vol. 106(27), P. 464-467.

6. Drug characterization/impurity profiling background and concepts. Manual for use by national law enforcement authorities and drug testing laboratories, 2001. [Electronic resource]: United Nations Office on Drugs and Crime [website]. URL: https://www.unodc.org/pdf/publications/st-nar-32rev1.pdf. 
7. Scientific and technical cooperation in the control of drug abuse and illicit trafficking; development of drug profiling/signature analysis in support of a scientific approach to law enforcement, Resolution 39/1, 1999. [Electronic resource]: United Nations Office on Drugs and Crime [website]. URL: https://www.unodc.org/unodc/en/commissions/CND/Resolutions_Decisions/ResolutionsDecisions_1990-1999.html.

8. Namera A., Kawamura M., Nakamoto A., Saito T. and Nagao M. Comprehensive review of the detection methods for synthetic cannabinoids and cathinones. Forensic Toxicology 2015. Vol. 33(2), P. 175-194.

9. Гладырев В.В., Дроздов М.А., Кедыс Д.Н. и др. Экспертное исследование курительных смесей, содержащих наиболее распространенные синтетические каннабиноиды. М.: ЭКУ 9 Департамента ФСКН России, 2010, 60 c. [Gladyrev V.V., Drozdov M.A., Kedys D.N. and others. An expert study of smoking blends containing the most common synthetic cannabinoids. Moscow: EKD 9 of the Department of Federal Drug Control Service of Russia, 2010. 60 p. (In Russ.)].

10. Kvasnica M. Dicyclohexylcarbodiimide (DCC). Synlett 2007. Vol. 2007 (14), P. 2306-2307.

11. 5F-APINACA (5F-AKB-48) Review Report Agenda item 4.10 Committee on Drug Dependence Thirty-eighth Meeting Geneva, 14-18 November 2016 [Electronic resource]: The World Health Organization (WHO) [website]. URL: http://www.who.int/medicines/access/controlledsubstances/4.10_5F-APINACA_CritReview.pdf.

12. XLR-11 Critical Review Report Agenda Item 4.12 Expert Committee on Drug Dependence Thirty-eighth Meeting Geneva, 14-18 November 2016 [Electronic resource]: The World Health Organization (WHO) [website]. URL: http://www.who.int/medicines/access/controlledsubstances/4.12_XLR-11_CritReview.pdf.

13. AB-PINACA Critical Review Report Agenda Item 4.4 Expert Committee on Drug Dependence Thirty-ninth Meeting Geneva, 6-10 November 2017 [Electronic resource]: The World Health Organization (WHO) [website]. URL: http://www.who.int/medicines/access/controlledsubstances/CriticalReview_ABPINACA.pdf.

14. 5F-PB-22 Critical Review Report Agenda Item 4.12 Expert Committee on Drug Dependence Thirty-ninth Meeting Geneva, 6-10 November 2017 [Electronic resource]: The World Health Organization (WHO) [website]. URL: http:/www.who.int/medicines/access/controlled-substances/ CriticalReview_5FPB22.pdf. 